\title{
Abilities of development support in children with genetic syndromes. Experiences from annual integrational meetings
}

\author{
Alina T Midro ${ }^{*}$, Olga Haus, Krystyna Kobel-Buys, Jolanta Wierzba, Stanisław Zajączek \\ From 5th European Conference on Rare Diseases (ECRD 2010) \\ Krakow, Poland. 13-15 May 2010
}

Recognition of a genetic syndrome, as a course of psychomotor development retardation, requires genetic counselling where a prognosis of development for children with different syndromes is given. Recent knowledge according respective genetic syndrome defines: how to diagnose them, describes the child's limits in comparison to coevals, usually do not obtain any data according to the child's abilities, which we may use in our stimulation advance with children during their individual developmental profile. The pessimistic vision of child's development leads towards social isolation and even isolation of the whole family. Looking for a solution against social isolation of children with genetic disorders with metal handicap and deprivation of their families motivated us to organise conferences, which would integrate clinical geneticists, other doctors, psychologists, pedagogues, therapists and families associated with support groups. This idea allowed for the building of a dialog platform between specialists, presenting the newest discoveries of native and European scientists and parents taking part in the conference together with children, as specific experts of their child. The meetings were a special form because individual and group medical and pedagogical consultations of patients and/or their families with medical students and young physician were included.The aim of respective conferences about such syndromes as Down s., Rett s., Prader-Willi s., Angelman s., Wolf-Hirschhorn s., Cat cry s., Russell-Silver s., Neurofibromatosis type I, Cornelia de Lange s. and Williams s. was to point out the necessity of a collaboration among different groups of specialists taking care of children with genetic disorders together with

*Correspondence: alinamidro@gmil.com

Waszyngtona str 13 PO Box 22, Białystok, 15-082, Poland parental support groups. This kind of collaboration is important for the recognition of the important role which parents play in the development of knowledge about genetic disorders and of public awareness.

Published: 19 October 2010

doi:10.1186/1750-1172-5-S1-P15

Cite this article as: Midro et al: Abilities of development support in children with genetic syndromes. Experiences from annual integrational meetings. Orphanet Journal of Rare Diseases 2010 5(Suppl 1):P15.
Submit your next manuscript to BioMed Central and take full advantage of:

- Convenient online submission

- Thorough peer review

- No space constraints or color figure charges

- Immediate publication on acceptance

- Inclusion in PubMled, CAS, Scopus and Google Scholar

- Research which is freely available for redistribution

Submit your manuscript at www.biomedcentral.com/submit
Biomed Central 